\title{
Bad or good neighbours: a spatial financial contagion study
}

\author{
Matteo Foglia, Alessandra Ortolano, Elisa Di Febo and \\ Eliana Angelini \\ Department of Economics, “G.d'Annunzio”University of Chieti-Pescara, \\ Pescara, Italy
}

\begin{abstract}
Purpose - The purpose of this paper is to study the evolution of financial contagion between Eurozone banks, observing the credit default swaps (CDSs) market during the period 2009-2017.

Design/methodology/approach - The authors use a dynamic spatial Durbin model that enables to explore the direct and indirect effects over the short and long run and the transmission channels of the contagion.

Findings - The results show how contagion emerges through physical and financial market links between banks. This finding implies that a bank can fail because people expect other related financial institutions to fail as well (self-fulfilling crisis). The study provides statistically significant evidence of the presence of credit risk spillovers in CDS markets. The findings show that equity market dynamics of "neighbouring" banks are important factors in risk transmission.

Originality/value - The research provides a new contribution to the analysis of EZ banking risk contagion, studying CDS spread determinants both under a temporal and spatial dimension. Considering the cross-dependence of credit spreads, the study allowed to verify the non-linearity between the probability of default of a debtor and the observed credit spreads (credit spread puzzle). The authors provide information on the transmission mechanism of contagion and, on the effects among the largest banks. In fact, through the study of short- and long-term impacts, direct and indirect, the paper classify banks of systemic importance according to their effect on the financial system.
\end{abstract}

Keywords Credit risk, Bad neighbourhood effect, Dynamic spatial Durbin model, Spatial contagion

Paper type Research paper

\section{Introduction}

The measurement of contagion is an important field of research both for academics and for policymakers, i.e. those responsible for monitoring the stability of financial markets. The global financial crisis (2007-2009) and the sovereign debt one (2010-present) have shown how the country, market, firm-specific risk can be quickly spread to another country/market/firm. These spillover effects may result from bilateral balance sheet links, counterparty risk,

(C) Matteo Foglia, Alessandra Ortolano, Elisa Di Febo and Eliana Angelini. Published by Emerald Publishing Limited. This article is published under the Creative Commons Attribution (CC BY 4.0) licence. Anyone may reproduce, distribute, translate and create derivative works of this article (for both commercial and non-commercial purposes), subject to full attribution to the original publication and authors. The full terms of this licence may be seen at http://creativecommons.org/licences/by/4.0/legalcode

Authors would like to express their sincere thanks to the Regional Economics Applications Laboratory (R.E.A.L) and Professor Sandy Dall'Erba for invaluable discussions on this line of enquiry. They also wish to thank participants of the International Conference "DySES - Systemic Risk", October 09-12/2018, Sorbonne University (Paris - France), for helpful comments and remarks. Finally, they would like to thank the editor and two anonymous referees for their highly constructive comments which make this paper more valuable. The usual disclaimer applies.

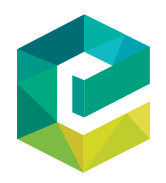

Studies in Economics and Finance Vol. 37 No. 4,2020 pp. $753-776$ Emerald Publishing Limited
$1086-7376$ DOI 10.1108/SEF-03-2020-0082 
financial market dynamics. Besides, the two crises have shown that dependencies in credit risks are more significant and imply a focus on the connections between them. Measuring and monitoring these links have important implications for financial contagion and systemic risk. Indeed, modern financial systems are very complicated entities, consisting of a large number of companies that create a dense "network" of links. In light of these events, which have involved the world's economies in recent times, the interest of the financial literature has increasingly turned to this phenomenon, that for a long time has been considered marginally. In the past, the systemic event was described by the "bank run" phenomenon, in which a bank failure was due to customer panic. This led to the withdrawal of savings by lenders, triggering a liquidity crisis that, in turn, caused the collapse of other banks, because of the connections between these companies. However, the financial crisis has shown that the systemic spread of risk is not only the result of difficulties experienced by large institutions. The systemic importance of the various actors also depends on their degree of interconnection.

In this regard, the paper aims to analyse and estimate the financial contagion between different banks in the Eurozone, considering the "network" structure of the banking system. The idea is to study cross-bank (financial) contagion to develop stress tests, taking into account the direct and indirect spillover effects. To do this, we use an advanced spatial econometric technique, namely, a dynamic spatial Durbin model (dySDM). Because of this method, we are able to analyse the contagion effect, and therefore, the existence of externalities among banks. Indeed, by including dependency between financial institutions, we can estimate direct and indirect effects (Lesage and Pace, 2014). The propagation of risk can be characterised by "Spatio-temporal" dependence which is a particular case of cross-section connection (Jing et al., 2018). For example, the structure of the correlation between observations is determined by each bank's position in credit flows. The model is estimated using data on credit default swap (CDS) spreads and financial links (such as financial claim and stock correlation) between 22 banks of the Eurozone from March 2009 to March 2017. It is essential to keep in mind the different definitions of contagion. Indeed, a long-standing debate in academic literature considers the semantics used to analyse financial transmission mechanisms with terms such as contagion, interdependence, interconnection or spillover. In this paper, we follow Blasque et al. (2016) and we interpret the spatial coefficient as a contagion parameter in the spirit of Forbes and Rigobon (2002). Hence, the spatial dependency coefficient provides a measure of changes in contagion within the euro bank.

Our work is close to the papers of Eder and Keiler (2015) and Foglia and Angelini (2019), that analyse the contagion risk applying a spatial autoregressive model (SAR). However, in contrast with them, we use a dySDM. The inclusion of lagged variables allows us to take into account the spatial and time lags. Not considering this design framework, could lead to an incorrect estimation of the effects. Indeed, in our model, we are able to show how the spatial dependence dynamics affect credit risk in the same period and also in future ones.

The results show how contagion emerges through physical and financial market links between banks. This finding implies that a bank can fail because people expect other related financial institutions to fail as well (self-fulfilling crisis). Our work provides statistically significant evidence of the presence of credit risk spillovers in CDS markets. Furthermore, using the dySDM, it has been possible to break down the total effect of financial shocks into direct and indirect effects, both over a short and long time. Our findings show that equity market dynamics of "neighbouring" banks are important factors in risk transmission, i.e. in the evolution of contagion.

This research contributes to the literature in several ways. Firstly, it analyses the determinants of bank credit risk for the Eurozone banking system, taking into account the Spatio-temporal interactions. Moreover, considering the cross-dependence of credit spreads, we are allowed to verify the non-linearity between the probability of default of a debtor and the observed credit spreads (credit spread puzzle), contrary to the use of classical panel models. 
Secondly, we provide information on the transmission mechanism of contagion, and therefore, on the effects among the largest banks. In fact, through the study of short- and long-term impacts, direct and indirect, we can classify banks of systemic importance according to their impact on the financial system and the basis of their reaction (fragility) to the change of other banks conditions (financial and fundamental). Also, our estimates not only take into account the dependence on cross-section but also include temporal interactions between banks, which are necessary components for a correct assessment of contagion.

In this regard, we deem that our work highlights three main issues for policymakers: the

Bad or good neighbours

relevance of system's risk-taking to individual credit risk; the need of improving the quality of the capital base; the necessity of a greater role of the ECB in managing the banking contagion.

\section{Banking credit default swap spread spillovers: an international overview}

Several CDS spillover phenomena, during the global financial turmoil of the past decade, have characterised CDS spread among banks in different ways, both under a geographical and structural perspective. Below we show a brief related literature review, focussed mostly on the banking sectors for the US, Europe, UK and Asia.

Apergis et al. (2019) study whether contagion occurred during the recent global financial crisis across European and US financial markets, adopting the same definition of contagion made by Forbes and Rigobon (2002), namely, the "shift-contagion". They analyse daily observations of bank sector CDS indices and equity, volatility, government bond, insurance sector CDS, for Europe and the US during the period 2004-2012. Their main results are the following. Within Europe, the authors show the presence of contagion between the equity index and the bank and insurance CDS indices. Furthermore, significant contagion effects deal with the insurance sector CDS to the banking sector CDS index and from the government bond to the equity index. Within the US, they observe that shocks propagate between the insurance sector CDS index and all other indices, except the equity index, affected only by the bank CDS index. Across regions, they observe that contagion runs from the US insurance CDS market to all the European indices, except for the equity index. Conversely, the US insurance CDS index is affected by both European CDS indices and the volatility index.

Cerrato et al. (2017) study the joint credit risk in the UK global systematically important banks during the period 2007-2015, using weekly CDS spreads. They apply the combination of the reduced-form model and the generalised autoregressive score-based dynamic asymmetric copula model to the CDS data, to measure systemic risk. They find that the time-varying and asymmetric dependence structure of the CDS spread changes, is closely related to the joint default probability that two or more banks simultaneously default and is mostly driven by market factors.

Bhar (2016) analyses the interconnectedness of the UK and US markets observing banking CDS indices for the period 2004-2010. The author applies Kalman filter convergence tests to the daily CDS index prices to measure the interconnectedness between these countries' credit sectors. He shows no statistically significant evidence, of short-run time-varying banking sector interconnectedness between the two markets. On the other hand, the author documents the steady-state long term interconnectedness. This fact might indicate a significant operational and structural alignment of financial institutions operating in these countries and similarity in investing conditions.

Alemany et al. (2015) compute an asymmetric multivariate BEKK model to measure cross-market volatility spillovers, using European CDS. The authors observe the impact of three significant events of credit risk volatility transmission (the subprime crisis, the bankruptcy of Lehman Brothers and the first bailout of Greece) firstly between Eurozone and non-Eurozone banks and then between distressed peripheral and core countries inside 
the Eurozone. Their results document that a unidirectional volatility shock spillover effect 37,4 characterises the global financial crisis in credit risk. Conversely, the third event, expression of the Eurozone debt crisis, seems to be local with the euro area acting as a firewall. In particular, they find a segmentation within the Eurozone between peripheral and nondistressed core countries.

Tamakoshi and Hamori (2014) analyse the volatility and mean transmissions between the CDSs indexes of three US financial sectors, namely, banking, insurance and financial services. They use daily series indexes from January 2004 to December 2011. The authors observe evidence of significant causality-in-mean effects running from the banking sector to the insurance and financial services sector CDS indexes and from the financial services to the insurance sector. Moreover, they find significant causality-in-variance effects from the financial services sector CDS index to the banking sector, implying the existence of information transmission and contagion from the former, the least regulated of the three.

Kim et al. (2010) analyse the spillovers of the US mortgage market to Asia. More specifically, they observe CDS spreads and EDFs for 38 corporate borrowers (including six banks) from the Asia-ex-Japan region, during the period January 2005-January 2007. They argue that the contagion was due to an amplification mechanism, caused by a global repricing of credit risk. Besides, the authors state that that valuation losses on CDS contracts for these Asian borrowers arose in part from movements in global and region-specific risk pricing factors, as well as from risk aversion expressed by the expected losses from defaults.

Compared to the aforementioned papers, our research offers a new contribution to the analysis of EZ banking risk contagion, studying CDS spread determinants both under a temporal and spatial dimension. By this method, we are able to capture the cross-dependence of credit spreads, i.e. the spillover mechanism of contagion. In particular, applying spatial design, we can test if CDS spread of one bank depends on the CDS spread of other banks.

\section{Literature review}

This section discusses the theoretical foundations and relevant studies for our analysis. It is divided into three different parts: one deals with recent works on banking CDS spreads, the second offer the major contributions on risk spillover (contagion), while the last concerns the principal papers on the spatial econometric methodology.

The main contributions of literature on CDS spread determinants are based on the observation of balance sheet variables, market and macroeconomic ones. Lee and Hyun (2019), study the impact of equity price jumps on CDS spread and find an asymmetric effect, in terms of a more pronounced impact of the negative jumps. Benbouzid et al. (2018) suggest that CDS spread is driven by asset quality, liquidity and operations income ratio; they also check for bank size, finding a non-monotonic impact on CDS spread. Chodnicka-Jaworska and Jaworski (2017) propose a study on CDS spread determinants adopting CAMELS, for a panel of European and American banks for the period 2004-2015. They find that the derivative is more sensitive to market risk factors, while the impact of capital adequacy, earnings and liquidity indicators is weaker. Analogously Li and Fu (2017), find that market value indicators (namely, Tobin's $Q$, stock market returns and interest rate) appear to be more important than book value indicators, as CDS determinants. Similar findings are shown by Samaniego-Medina et al. (2016), who show great explanatory power for market variables in terms of market equity return and volatility, whereas, as concerns accounting variables, they find significance for the non-performing loan ratio, the capitalisation ratio and liquidity proxies. Annaert et al. (2013), identify three kinds of spread determinants for euro area institutions, namely, credit risk factors, trading liquidity and market-wide factors. 
Specifically, on the balance sheet indicators, Chiaramonte and Casu (2013) highlight the significance of the indicator of the quality of assets' portfolio, as a predictor of default. As concerns leverage ratio, they find that the CDS market has lacked attention to the high levels of this ratio until the outbreak of the financial crisis. The lows explanatory power of leverage ratio for the banking sector are shown by Düllmann and Sosinska (2007) and Kalemli-Ozcan et al. (2012). Angelini and Ortolano (2016) investigate, for European countries, the relationship between the movement of banking CDS spread and balance sheet variables. The results highlight the important role of speculation in contrast to the fundamental variables.

The second strand of literature analyses the risk spillover effect (contagion) on the financial system [1]. Most studies use a network approach to investigate the interconnectedness between financial institutions. One of the most important works is the study of Billio et al. (2012) that examine the network topologies of the financial system. Using Granger causality, the authors compute several measures of interconnectedness between banks, insurances and hedge funds. Diebold and Yilmaz (2014) estimate the spillover effect through the application of an auto-regressive vector model (VAR). They show a strong interconnection between the major US financial institutions during the global financial crisis. Further, Giudici and Parisi (2018) compute a new systemic risk measure, namely, the CoRisk. Their measure combines vector autoregressive regression with correlation networks. More recently, Foglia and Angelini (2020) analyse the tail risk spillover between insurance companies, banks and shadow banking system in the Eurozone through the Tail-Event driven NETwork (TENET) risk model. Their findings suggest the key role of shadow banking in risk transmission.

Other works use marked-based measures to capture cross-sectional contagion. For example, the CoVaR model (Adrian and Brunnermeier, 2016), the SRISK measure proposed by Brownless and Engle (2017). Ghulam and Doering (2018), by VaR quantile regression, analyse the risk transmission between german and UK financial institutions. Daly et al. (2019) investigate the contagion risk for the global environment using various risk measures (distance to default, distance to the capital and distance to insolvency) by using the multinomial logistic model. The authors show the strong correlation between the UK and US financial sector, i.e. high level of contagion. Fan et al. (2020) study the spillover effects of capital controls on capital flow and financial risk contagion. The authors document that "tightening capital controls can increase the exposure of other similar countries to global financial risk by capital flows".

The literature on the methodological approach is relatively recent. Pino and Sharma (2019) use spatial econometrics to investigate the channels of bank contagion, that can be useful to preserve the stability of the US banking sector. The results show that there is no contagion when the change in the risk-taking of a specific bank is assumed to affect all other banks in the US banking sector. Nevertheless, an important contagion effect is verified for banks that belong to the same state, the same Federal-Reserve district and the same size. Foglia and Angelini (2019) estimated the contagion spillover risk between Eurozone bank using the Blasques et al. (2016) model. Their results suggest that the contagion depends on the bank's "proximity", highlighting how the systemic risk is persistent in the euro area banks. Debarsy et al. (2018) analyse tree aspects: the effective transmission channels of international risk spillovers across countries, the most dominant ones and which countries are most at risk for their environment. Kişla and Önder (2018) analyse the macroeconomic determinants of sovereign risks for emerging markets, by considering spatial linkages such as the financial link and the trade linkage. Their results show that financial linkages are the most important channels to transfer the credit sovereign risk. Zhang et al. (2018) propose a dynamic spatial panel with the generalised autoregressive conditional heteroscedastic 
model (DSP-GJR-GARCH), that is able to capture the Spatio-temporal dependence. Their results show how their model improves the forecasting performance of international portfolio stock returns. Mili (2018) explores systemic risk spillovers between sovereign CDS return in eight European countries over the period 2006-2016. The methodology used is a spatial model that decomposes the CDS returns into a systemic, systematic and idiosyncratic risk premium, following the approach of Eder and Keiler (2015). The latter apply SAR model to quantify the contagion risk between systemically important financial institutions (SIFIs). They find that contagion "varies by geographical region and by the time", suggesting that market liquidity plays an important role to analyse the co-movement of CDS spread and the abnormal stock return of firms. Calabrese et al. (2017) indicate a measure of contagion risk based on the spatial autocorrelation parameter of a binary spatial autoregressive model. Blasques et al. (2016) extend the static SAR model and use spatial weights, based on cross-border lending data and European sovereign CDS spread data, over the period 2009-2014. During the sovereign debt crisis, the empirical evidence shows the effects of contagion in terms of high, time-varying spatial spillovers in the credit riskiness of European sovereigns. Dell'Erba et al. (2013) analyse the issue of spillovers by using lowfrequency data through the spatial econometric techniques, which allow understanding if the geographical proximity explains contagion in sovereign spreads.

\section{Data}

In this paper, we use the variation (log differences; $\Delta$ ) of banks' 5 -years CDS spread as a credit risk measure (i.e. as the dependent variable) as it reflects the change in investors' credit risk perception. The balanced panel consists of 22 major Eurozone banks [2]. Table 1 reports each bank's information, including the country where the bank's registered office is located, its ticker code, the full name, total asset and market capitalisation (December 2017).

As we can see, in the first five positions, there are three French banks. This shows how the French banking sector is the second largest in Europe after the British banking sector, and therefore the largest in the Eurozone (FBF, 2015). In fact, among the eight eurozone banks defined as G-SIB [3] (global systemic banks), there are 3 French banks (BNP Paribas, Crédit Agricole, Société Générale), 1 Spanish bank, 1 German bank, 1 Italian bank and 1 Dutch bank.

All data are obtained by datastream. The estimation period spans from March 2009 to December 2017 (106 Obs.) at a monthly frequency. Specifically, we obtained monthly CDS spread directly from the data set, while, as balance sheet data are available on quarterly time series, we interpolate these variables with a cubic spline as in Eder and Keiler (2015).

More specifically a CDS is a credit derivative, whose aim is protecting the buyer against an event of default dealing with the issuer of the underlying. Its price, called the spread, is an expression of the creditworthiness of the reference entity. A relevant issue deals with counterparty risk, namely, the risk that CDS protection seller does not respect the commitments proposed in the original contract, reducing the value of default insurance and increasing systemic risk. For example, when the AIG rating was downgraded (from AA- to A), the company was forced to provide additional collateral on the mortgage-backed CDS positions, but the AIG was not able to do it (Kiff et al., 2009). As a result, AIG was in default and the problem was aggravated by the concentration of participants in the CDS market. Indeed, when a seller (in this case AIG) does not repay its debts, this fact has an impact on other dealers and even in other markets. Failures by protection vendors, increase the default contagion, and therefore systemic risk. For this reason, we use the CDS spread to measure it. High levels of credit risk (CDS) reflect high levels of systemic risk and vice-versa.

In this context, the analysis of CDS spread determinants, as shown by literature, is an indicator of the main factors (independent variables), that affect banking credit risk. In 


\begin{tabular}{|c|c|c|c|c|c|c|c|}
\hline Country & Ticker & Banks & $\begin{array}{l}\text { Total asset } \\
\text { (2017) }\end{array}$ & $\begin{array}{l}\text { Mark. cap. } \\
\text { (2017) }\end{array}$ & Rank of T.A. & Rank of MC & $\begin{array}{l}\text { Bad or good } \\
\text { neighbours }\end{array}$ \\
\hline AT & EBS & Erste Group Bank AG & $220,659.00$ & $17,449.88$ & 13 & 12 & \\
\hline AT & RBI & Raiffeisen Bank International & $135,146.00$ & $9,210.30$ & 16 & 14 & \\
\hline $\mathrm{BE}$ & $\mathrm{KBC}$ & KBC Groep NV & $292,342.00$ & $30,306.45$ & 12 & 9 & \\
\hline FR & BNP & BNP Paribas SA & $1,949,771.00$ & $79,901.94$ & 1 & 2 & \\
\hline FR & $\mathrm{ACA}$ & Credit Agricole & $1,551,600.00$ & $38,806.61$ & 2 & 7 & 759 \\
\hline FR & GLE & Societe Generale SA & $1,274,200.00$ & $36,723.90$ & 5 & 8 & \\
\hline $\mathrm{DE}$ & $\mathrm{KN}$ & Natixis SA & $519,987.00$ & $21,378.14$ & 10 & 11 & \\
\hline $\mathrm{DE}$ & CBK & Commerzbank & $452,513.00$ & $13,400.23$ & 11 & 13 & \\
\hline $\mathrm{DE}$ & DBK & Deutsche Bank & $1,474,732.00$ & $23,470.27$ & 3 & 10 & \\
\hline GR & ALBKY & Alpha bank & $60,813.00$ & $3,380.70$ & 21 & 20 & \\
\hline GR & NBGIF & National Bank of Greece & $59,852.00$ & $3,164.91$ & 22 & 21 & \\
\hline IE & BIRG & Bank of Ireland Group & $121,317.00$ & $8,037.23$ & 17 & 17 & \\
\hline IT & BMPS & Banca Monte Paschi di Siena & $136,217.41$ & $3,058.26$ & 15 & 22 & \\
\hline IT & MB & Medio Banca & $69,730.21$ & $8,920.13$ & 19 & 16 & \\
\hline IT & UCG & Unicredit & $826,171.14$ & $40,085.20$ & 7 & 6 & \\
\hline IT & ISP & Intesa San Paolo & $783,662.00$ & $50,069.30$ & 8 & 4 & \\
\hline NL & INGA & ING & $845,398.00$ & $54,339.25$ & 6 & 3 & \\
\hline PT & $\mathrm{BCP}$ & Banco Comrpotugue SR & $68,801.68$ & $4,203.20$ & 20 & 19 & \\
\hline ES & $\mathrm{SAB}$ & Banco de Sabadell & $214,816.47$ & $9,152.25$ & 14 & 15 & \\
\hline ES & SAN & Banco Santander & $1,421,095.00$ & $86,699.50$ & 4 & 1 & \\
\hline ES & BKT & Bankinter & $71,144.47$ & $7,802.15$ & 18 & 18 & \\
\hline ES & BBVA & BBV Argentaria & $675,334.00$ & $44,874.83$ & 9 & 5 & \\
\hline
\end{tabular}

Notes: Table reports the 22 banks in the sample. The first column shows the country where the bank's registered office is located, the second the ticker, the third the name of the banks, the fourth the total asset (T.A.), the fifth the market capitalisation (MC). Total assets and market capitalisations are in millions of Euro as of December 2017

Table 1. Bank sample

particular, we include three fundamental balance-sheet variables (Tier 1, total asset and leverage), two bank financial market variables (stock return and stock volatility), one common local country variables (term spread) and two common factors. More specifically, we include the monetary policy and a dummy variable to take into account the agreement by the European Parliament and the Council of the European Union (October 2011).

\subsection{Explanatory variables}

Tier 1 (TIER 1) is given by the ratio of capital over a risk-weighted asset. The higher the capital buffer, the lower the bank credit risk. In general, banks' capital requirements are very relevant aspects of the Basel III framework against credit risk. This is particularly true, considering banking usage of regulatory arbitrage adopting credit derivatives, like CDSs themselves (Thornton and di Tommaso, 2018). In this field, its clear that banks' risky assets may erode their capital: that is, a higher level of Tier 1 ratio is connected to lower level credit risk in the portfolio (Witowschi and Luca, 2016).

Total asset (T.A) captures the size of a bank (we use the natural logarithm). This variable might take opposite signs: as larger banks could be more attracted by greater risk-taking (that is the "too big to fail" issue; Barth and Wihlborg, 2016), there should be a positive relationship between CDS spread and total asset; however, larger banks may be more resilient to market shock by their efficient management, benefiting from economies of scale.

We compute the leverage $(L E V)$ as a ratio of total liabilities over total liabilities plus market capitalisation, following the approach of Eder and Keiler (2015). An increase of 
SEF

37,4

760

leverage implies an increase in the probability of default, namely, bounds of default (Annaert et al., 2013). This is especially important in a context of systemic distress, as the worsening of assets, also due to macroeconomic factors, is more destabilizing if the level of equity is too low with respect to debt (Bonaccorsi di Patti et al., 2016).

Equity returns reflect a firm's future prospects. In fact, positive returns indicate a lower risk of default and may, therefore, lead to lower spreads, while negative returns may indicate difficult situations, then an increase of default probability (Zhang et al., 2009). Therefore, we expect a negative relationship between stock return and the CDS spread.

According to structural models (Merton, 1974), the probability of default is measured as the probability that the company's asset value gets lower than debt: hence, it is affected by asset volatility. A proxy of the latter is equity volatility (equity $\sigma$ ), as suggested by these models. We compute this variable using a $\operatorname{GARCH}(1,1)$ model of daily stock return [4]. So, as asset volatility increases the probability that the default threshold will be reached (Alexander and Kaeck, 2008), we expect a positive relationship between this variable and the CDS spread.

We include the term spread (term-spread) as the difference between 10-year bond yield and 2-year bond yield, namely, the slope of the term structure (Collin-Dufresn et al., 2001; Alexander and Kaeck, 2008). Specifically, the literature describes a negative relation between the slope of term structure and CDS spread. This is due by the fact that this variable influences the movement of risk-free rate: according to structural models one more time, higher levels of the latter raises the risk-neutral drift and decreases the probability of default. Moreover, under another perspective, the steepness of the term curve suggests an improvement of economic growth and vice-versa.

Moreover, to take into account the ECB monetary policy effect on contagion risk, we compute the shadow-rate as a measure of monetary stance (shadow-rate). Specifically, we use a unique index of monetary policy, i.e. a measure able to take into account the conventional and unconventional policy in a zero lower bound era (see Krippner, 2015). We follow the approach of Pattipeilohy et al. (2017), namely, we use factor analysis to extract the two components from the yield curve provided by ECB DataWarehouse [5].

Finally, to understand the possible change in liquidity on CDS spread after the agreement for the limitation of CDS in Europe (October 2011), we create a dummy variable (dummy), that is equal to 0 for the period before the announcement and, is equal to 1 for the period afterwards.

Table 2 shows the summary statistics of the entire sample, while Table 3 gives further detail of covariates.

\begin{tabular}{lcccc}
\hline Variable & Mean & SD & Min & Max \\
\hline$\Delta$ CDS spread & -0.014 & 0.171 & -0.791 & 1.148 \\
TIER 1 & 11.81 & 2.228 & 0.383 & 18.31 \\
T.A. & 12.73 & 1.174 & 10.88 & 14.58 \\
LEV & 0.957 & 0.025 & 0.87 & 1.000 \\
Stock return & -0.004 & 0.149 & -2.121 & 1.039 \\
Equity $\sigma$ & 10.08 & 17.10 & 0.000 & 299.8 \\
Term-spread & -1.401 & 5.864 & -30.58 & 56.38 \\
Shadow-rate & -0.0531 & 0.195 & -0.729 & 0.579 \\
Dummy & 0.696 & 0.459 & 0 & 1
\end{tabular}

Table 2.

Note: Table reports summary statistics for the variables, covering the period March 2009-December 2017 
Moreover, according to the panel unit root test (Table 4), all variables are stationary.

Figure 1 shows the dynamics of the CDS spread average (blue), the stock volatility average (violet) and the cumulative average return (green), from March 2009 to December 2017. The inverse relationship between CDS spread and stock return is clear. The stock market hit bottom during 2011-2012 and again during 2016. This match substantial peaks in values in CDS spread. Moreover, the trend of the volatility shows how the high peaks correspond to the sovereign debt crisis timeline.

Bad or good neighbours

\section{Econometric model}

To test if a bank's credit default is transmitted to another bank via exposure channel, we use a spatial econometric approach. The model used in this paper is a dynamic version of the Spatial Durbin Model. We can explain the "time-space dynamics" (Elhorst, 2014) of contagion by incorporating the spatial term into a panel setting.

The dySDM is given by:

$$
y_{i t}=\varphi y_{i t-1}+\eta W y_{i t-1}+\rho W y_{i t}+x_{i t} \beta_{1}+W x_{i t} \beta_{2}+\mu+\varepsilon_{t}
$$

where $y_{i t}$ is the log differences of CDS spread for bank $i$ at time $t$, while $y_{i t-1}$ is the lagged value; the vector $x_{i t}$ is composed by the following variables, namely, TIER 1, T.A., LEV,

\begin{tabular}{|c|c|c|c|c|c|c|c|c|}
\hline Variables & Tier 1 & T.A. & LEV & Stock return & Equity $\sigma$ & Term-spread & Shadow-rate & Dummy \\
\hline TIER 1 & 1 & & & & & & & \\
\hline T.A. & 0.077 & 1 & & & & & & \\
\hline LEV & -0.221 & 0.400 & 1 & & & & & \\
\hline Stock return & 0.023 & 0.046 & -0.124 & 1 & & & & \\
\hline Equity $\sigma$ & -0.156 & -0.231 & 0.213 & -0.346 & 1 & & & \\
\hline Term-spread & 0.225 & -0.065 & -0.220 & -0.031 & -0.039 & 1 & & \\
\hline Shadow-rate & 0.082 & -0.002 & -0.069 & -0.050 & -0.076 & 0.031 & 1 & \\
\hline Dummy & 0.484 & 0.004 & -0.082 & 0.025 & -0.044 & 0.114 & -0.031 & 1 \\
\hline
\end{tabular}

Notes: Table shows the Spearman rank correlation between the independent variables. Italic values stand for significantly different from 0 at the $5 \%$

Table 3.

Spearman rank correlation

\begin{tabular}{lcr}
\hline Variables & Statistics & $p$-value \\
\hline$\triangle C D S$ & -32.65 & 0.000 \\
TIER 1 & -2.395 & 0.008 \\
T.A. & -8.119 & 0.000 \\
LEV & -2.147 & 0.015 \\
Stock return & -37.39 & 0.000 \\
Equity $\sigma$ & -23.88 & 0.000 \\
Term-spread & -4.741 & 0.000 \\
Shadow-rate & -28.61 & 0.000 \\
Dummy & -3.212 & 0.000
\end{tabular}

Notes: Im-Pesaran-Shin unit-root test. Test for the presence of unit roots that combines information from the time series dimension with the cross-section dimension. ADF regressions are performed with one lag. All variables are stationary at $1 \%$ ( $p$-value less than 0.01$)$ as the test confirms

Table 4. Unit root test 
SEF

37,4

\section{2}

Figure 1.

The dynamic of stock market and CDS spread.

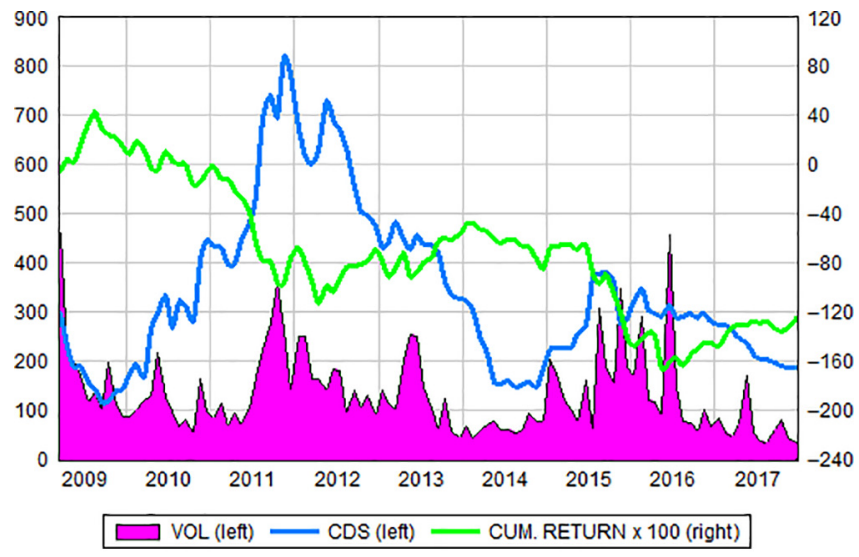

Note: Time series plot of the market volatility (pink), mean CDS spread (blue) and cumulative stock return (green)

stock return, equity $\sigma$, term-spread, shadow-rate and dummy observed for each $i$ and $t$. In particular, $\beta_{1}$ is the coefficient that measures the effect of changes in the vector's variables on each bank CDS spread. $W$ is the $N x N$ standardised weighted contiguity matrix, i.e. the interaction term between the observations. It captures the relationship between banks, therefore how the credit risk of bank $i$ is affected by the credit risk of bank $j$. $W y_{i t}$ captures the contemporaneous interactions across the $N$ bank while $W y_{i t-1}$ models the time-lagged interactions. This implies that the CDS spread of bank $i$ at monthly $t$ is explained by the initial level of the CDS spread in the previous month, both of the bank itself $\left(y_{i t-1}\right)$ and of the latter multiplied by the contiguity matrix $\left(W y_{i t-1}\right)$ (Elhorst et al., 2013). $\beta_{2}$ is a $K x 1$ vector of the coefficients which takes into account the effect of changes in the specific variables of other banks on the credit risk of bank $i$. The coefficient $\rho$ is the spatial autocorrelation coefficient that measures the spillover effect that arises from the value of CDS spread in "neighbouring" banks. $\varphi$ is the autoregressive time dependence parameter and $\eta$ is defined as the Spatio-temporal diffusion parameter (Debarsy et al., 2012). $\varepsilon_{t}$ is the i.i.d. error term, while $\mu$ stands for the individual bank effects with $\mu \sim N\left(0, \delta_{\mu}^{2}\right)$.

The advantage of using this model is twofold. First of all, the model allows us to capture both dependencies with directly connected banks (direct spillovers) and dependencies with banks that are not directly exposed (indirect spillovers). The estimation of these indirect effects is useful for policy-makers (e.g. financial stability board), as it allows to distinguish the local effect of an intervention (e.g. bail-out) and the effects induced by other banks. Therefore, indirect effects may reflect the fragility of credit risk for one bank due to specific factors of other banks. Secondly, by including delayed variables, dySDM allows spatial dependency not only to impact credit risk in the same period but also to be spread to future ones. These short and long-run effects allow us to understand the dynamics of contagion, i.e. how variables react to different time shocks.

The effect of the credit risk of bank $i$ arising from the change in the covariate variables will affect the unit itself and all other banks indirectly. We use the term spillover to identify the 
contemporaneous effect that involves in the same time, while we refer as diffusion term (Spatiotemporal) to identify an effect that involves in a different period (Debarsy et al., 2012).

Hence, the short-run effect:

$$
\left[\frac{\partial E(y)}{\partial x_{1 k}} \ldots \frac{\partial E(y)}{\partial x_{N k}}\right]=(\boldsymbol{I}-\rho \boldsymbol{W})^{-1}\left[\beta_{1 k} \boldsymbol{I}_{N}+\boldsymbol{\beta}_{2 k} \boldsymbol{W}\right]
$$

while the long-run effect:

$$
\left[\frac{\partial E(y)}{\partial x_{1 k}} \ldots \frac{\partial E(y)}{\partial x_{N k}}\right]=[(1-\varphi) \boldsymbol{I}-(\rho+\eta) \boldsymbol{W}]^{-1}\left[\beta_{1 k} \boldsymbol{I}_{N}+\beta_{2 k} \boldsymbol{W}\right]
$$

There are not short-run indirect effect, (Equation (2)) if $\rho=0$ and $\beta_{2 k}=0$, as well as there are no long-run effects if $\rho=-\eta$ and $\beta_{2 k}=0$ (Equation (3)).

\subsection{Building the weighted matrix (W)}

Hellwig (2014) shows that there are different channels of propagation of shock, for example, via physical exposures (claim and liabilities), via Information-based (systemic run) and via market and price. Following Foglia and Angelini (2019), we consider these channels by using three different interaction matrices. The first one is based on the financial claim, provided by BIS, (as in Milcheva and Zhu, 2016; Calabrese et al., 2017; Tonzer, 2015) to incorporate the physical exposures. In particular, the weights are constructed from bilateral interbank exposures among $n$ countries. Hence, $n \times n$ spatial weight matrix $W_{i j}$ is given by:

$$
W_{i j}=\left[\begin{array}{cccc}
0 & w_{12} & \cdots & w_{1 n} \\
w_{21} & 0 & \cdots & w_{2 n} \\
\vdots & \vdots & \ddots & \vdots \\
w_{n 1} & w_{n 2} & \cdots & 0
\end{array}\right]
$$

where $W_{i j}$ is the weight that corresponds to country pair $i j$, i.e. $w_{i j}=\frac{x_{i j}}{\sum_{j, i=1}^{n} x_{i j}}$ in such a way that the interbank assets (liabilities) positions of the banking system in the country $i$ vis-à-vis banks in country $j$, are divided by the total assets (liabilities) that the country $i$ has vis-à-vis all other countries $j$ in the sample (Tonzer, 2015).

The second one is built using a Spearman correlation of stock return, according to Fernandez (2011) approach, to capture the market and price exposure (the spiral of co-sell assets). In particular, each element of the matrix $W_{i j}$ is given by:

$$
w_{i, j}= \begin{cases}\frac{\exp \left(-d_{i, j}\right)}{\sum_{k=1}^{N}\left(-d_{i, k}\right)} & \text { if } i \neq j \\ 0 & \text { otherwise }\end{cases}
$$

where $d_{i, j}$ is the Euclidean distance defined by $d_{i, j}=\sqrt{2\left(1-\rho_{i, j}\right)}$, while $\rho_{i, j}$ is empirical spearman correlation coefficient associated with two banks $i$ and $j[6]$. 
SEF

37,4

764

Finally, the residual matrix is able to model the information transmission channel (financial link). To do this, following Dell' Erba et al. (2013), we use the financial flows, defined as the bilateral share of portfolio investment [7].

All the interaction matrices were built by collecting data before 2008, to avoid endogeneity problems [8]. In particular, we use the claim matrix and financial link matrix of 2007 at second-quarter period, while as "information" matrix, the weighted matrix is constructed by lagging the correlations by one year (i.e. we did not use data after 2008, as in Eder and Keiler, 2015). Finally, we standardise the weighted matrix by the classical rule, namely, row standardisation, such that for each $i, \Rightarrow \sum_{\mathrm{i}} \mathrm{w}_{\mathrm{i}, \mathrm{j}}=1$.

\section{Estimation results}

Table 5 reports the estimation results for the dySDM using bilateral bank claims as a measure of banks "neighbouring". In particular, we estimate the model with only the time lag (Column 1), with only the spatial lag (Column 2) and with time-spatial lags (Column 3). The table shows how the time-spatial model better fits the data (greater log-likelihood),

\begin{tabular}{|c|c|c|c|}
\hline Variables & CLAIMTime-lag & CLAIMSpace-lag & CLAIMSpace-time lag \\
\hline$\varphi$ & $-0.012(0.014)$ & & $-0.052 * * *(0.020)$ \\
\hline$\eta$ & & $0.026(0.018)$ & $0.071 * * * *(0.026)$ \\
\hline$\rho$ & $0.652^{* * *}(0.019)$ & $0.656^{* * *}(0.019)$ & $0.657 * * *(0.020)$ \\
\hline \multicolumn{4}{|l|}{$\beta_{1}$} \\
\hline TIER 1 & $0.001(0.001)$ & $0.001(0.001)$ & $0.001(0.001)$ \\
\hline T.A. & $-0.001(0.005)$ & $-0.001(0.005)$ & $-0.001(0.005)$ \\
\hline LEV & $-0.001(0.188)$ & $-0.014(0.188)$ & $-0.017(0.189)$ \\
\hline Stock return & $-0.088 * * *(0.022)$ & $-0.088^{* * * *}(0.022)$ & $-0.089 * * *(0.022)$ \\
\hline Equity $\sigma$ & $-0.081 * * *(0.019)$ & $-0.081^{* * * *}(0.019)$ & $-0.077 * * *(0.019)$ \\
\hline Term-spread & $-0.015^{* * * *}(0.004)$ & $-0.015^{* * *}(0.000)$ & $-0.016 * * *(0.000)$ \\
\hline Shadow-rate & $-0.247(0.587)$ & $-0.245(0.023)$ & $-0.282(0.589)$ \\
\hline Dummy & $-0.103 * *(0.050)$ & $-0.105^{* *}(0.050)$ & $-0.106 * *(0.050)$ \\
\hline \multicolumn{4}{|l|}{$\beta_{2}$} \\
\hline TIER 1 & $-0.008 *(0.004)$ & $-0.008 *(0.004)$ & $-0.008 *(0.004)$ \\
\hline T.A. & $-0.079 *(0.039)$ & $0.070 *(0.038)$ & $0.073 *(0.039)$ \\
\hline LEV & $-0.044(0.487)$ & $-0.110(0.487)$ & $-0.115(0.483)$ \\
\hline Stock return & $-0.238 * * *(0.040)$ & $-0.236^{* * *}(0.041)$ & $-0.234 * * *(0.040)$ \\
\hline Equity $\sigma$ & $-0.076(0.059)$ & $-0.083(0.059)$ & $-0.085(0.059)$ \\
\hline Term-spread & $0.011(0.061)$ & $0.001(0.006)$ & $0.009(0.006)$ \\
\hline Shadow-rate & $0.247(0.586)$ & $0.245(0.586)$ & $0.281(0.582)$ \\
\hline Dummy & $0.103 * *(0.050)$ & $0.105^{* *}(0.050)$ & $0.106^{* *}(0.050)$ \\
\hline Obs. & 2,332 & 2,332 & 2,332 \\
\hline$R$-squared & 0.32 & 0.32 & 0.35 \\
\hline $\operatorname{LogL}$ & $1,666.98$ & $1,667.41$ & $1,671.65$ \\
\hline AIC & $-3,186.85$ & $-3,296.83$ & $-3,303.58$ \\
\hline No. of banks & 22 & 22 & 22 \\
\hline Bank FE & YES & YES & YES \\
\hline
\end{tabular}

Table 5.

Dynamic Durbin model results
Notes: Estimation from the dynamic spatial Durbin model. In Column 2, the results for model estimation only with a temporal lag. Column 3 shows the results with spatial lag only. Column 4 shows the results, including temporal and spatial lag. Standard errors in parentheses. ***, ** and * significant at the 0.01, 0.05 and 0.10 level, respectively 
suggesting the decisive role of treating risk both under time and spatial perspective (both delays are significant at $1 \%$ ).

The spatial coefficient $\rho$ is significant at $1 \%$, meaning that there is a significant comovement across the credit risk, i.e. the contagion is present. This implies that the higher the bank's exposure, the stronger the co-movement with the counterparties will be, the higher the degree of spatial dependence in CDS "returns" $(\rho=0.65)$. We can note that both parameters $\varphi$ and $\eta$, which capture the time interactions and the spatial iterations between banks, are significant [9]. Therefore, these transmission channels are relevant for studying the dynamics of credit risk within the euro area. The time interaction coefficient is negative, therefore the lagged CDS spread change has a negative effect on CDS spread. An increase in the $\Delta \mathrm{CDS}$ spread is followed by decreases and vice-versa. This shows that the changes in CDS spread is not persistent (Khiewngamdee et al., 2017), i.e. changes in the CDS spread are mean-reverting. Hence, the reversal of CDS "return" could be a measure of the illiquidity of the market. In fact, if the CDS market is illiquid, changes in the CDS spread will be negatively auto-correlated (Tang and Yan, 2017). The domestic TIER 1 and the domestic leverage $(L E V)$ are not significant: this fact corroborates the analysis of Chiaramonte and Casu (2013), who found that these variables do not explain the credit risk.

As for the remaining variables of the model, all market bank-specific ones are significant with the expected sign (according to our assumptions), except for equity volatility (equity $\sigma$ ). The negative sign obtained could appear as contradictory, but this is not the case. In the event of increased equity volatility, and therefore greater risk, capital tends to shift from risky assets to safe ones (flight-to-quality effect). This generates an increase in the credit risk spread of the former and a decrease in the yields of the latter (Jubinski and Lipton, 2012; Fuerst et al., 2015; Gubareva and Borges, 2016; Foglia and Angelini, 2019). However, it contradicts those obtained by Samaniego-Medina (2016), which showed that equity volatility has a positive sign.

By concentrating on monetary policy, we can see that it is not significant. In fact, the results suggest that monetary policy is not a determinant of risk: we suppose that it might be due by the fact that ECB's primary objective is price stability and by the European "one size fits all" monetary policy (Wynne and Koech, 2012). Notwithstanding, although in recent years macro- and micro-prudential policy measures have been implemented for financial stability, the analysis suggests that they were not so incisive, both in the pre-crisis period and after the adoption of non-standard monetary policies (Sahling, 2017). The dummy estimate underlines the fact that there is a significant positive effect on CDS spread change after the introduction of regulation. Therefore, in light of our results, we guess that regulation may have had an impact on the liquidity of CDS market; notwithstanding, through our analysis, we are not able to affirm the direction of the variation.

Focussing on $\beta_{2}$ coefficient, TIER 1 , total asset, stock returns have significant effects and expected signs. These results illustrate the effect of neighbours on the credit risk of bank $i$. However, these coefficients show the opposite signs (except for stocks return) to the same variables that capture internal effects. This can be interpreted as investment mobility (i.e. a portfolio diversification).

An increase in TIER 1's neighbours, as well in their stock return, leads to a reduction in domestic credit risk while an increase in assets increases it ("herd effect"). According to Hellwing (2014), the contagion of hysteria can take the form of systematic disproportionate responses to small changes in fundamentals. A small change in fundamentals can produce a large variation in aggregate behaviour, for example, by causing many investors to run because they expect many others to do so as well ("run to others"). This shows the key role of the financial system on shock and risk transmission. An increase of total asset (risk- 
SEF

37,4

766

taking) of all system also affects individual credit risk. The belief of bailout due to the "too big to fail" effect eases excessive risk-taking dynamics among banks, according to the moral hazard theory (De Jonghe, 2010). Therefore, our results imply that for the Eurozone banking system, scale economies for large banks are affected by "too-big-to-fail" effect as showed by (Beccalli et al., 2015). Moreover, an increase in TIER 1 (capital adequacy) of neighbours has a beneficial effect on bank $i$. Increased security/resilience of the financial system implies greater credibility of individual bank investors. Our findings are in line with the hypothesis of Benbouzid et al. (2018) and Chiaramonte and Casu (2013), that find the same important effect on reduction credit risk due by the capital buffers.

Very interesting is the sign of the dummy with the iteration of neighbouring banks. In this case, it has a positive sign, so it implies more risk for bank $i$. This change testifies how even if the risk has been reduced - if we consider the whole banking network, the risk relationships between banks has remained unchanged.

The information provided by the dySDM suggests that bank credit risks are contagious. The spillover effect is high, showing how the systemic risk in the Eurozone banking system is present: the higher the contagion, the higher the probability of systemic risk. Moreover, the weighted financial claim matrix provided significant interaction coefficients. This suggests that the banks of Eurozone are connected by this channel of contagion, as suggest by Hellwing (2014).

\subsection{Stress-test study}

To compare the direct and indirect effects of the explanatory variables, we compute our estimates using the CLAIM weighted matrix. Table 6 shows the estimates of the spatial effects (estimate of indirect effects), both in the short and long term. As discussed above, the direct effect shows the effect of the variations of its fundamentals once the spatial multiplier is taken into account, while the indirect effect measures the impact on the diffusion of the changes in the fundamentals of the other $k$ banks, through the spatial multiplier (Dell'Erba et al., 2013; Kişla and Önder, 2018). In other words, the indirect effect compared to the direct impact, reveals the vulnerability of banks to financial contagion (Eder and Keiler, 2015). Total effects are the sum of the direct and indirect effects.

To keep our analysis easy to interpret, we consider only three impacts (stress-test): the variation of TIER 1 , the variation of the total asset and the variation of the stock return. The findings evidence the spillover effects along these three channels (variables).

Firstly, we can observe how the estimated coefficients of the effects differ from the estimates of the coefficients in Table 5. This is due to the feedback effects that derive from impacts that pass through neighbouring banks and return to the banks themselves (Elhorst, 2014). The total effects estimates are all significant. These estimates suggest that a $1 \%$ increase in a bank's TIER 1 (or stock return) will decrease the CDS spread by $0.02 \%(0.94 \%)$.

\begin{tabular}{lcccc}
\hline EFFECT & MATRIX & TIER 1 & T.A. & STOCK RETURN \\
\hline SHORT-RUN DIRECT & CLAIM & 0.001 & 0.006 & $-0.115^{* * * *}$ \\
SHORT-RUN INDIRECT & CLAIM & $-0.021^{* * *}$ & $0.215^{* * *}$ & $-0.822^{* * * *}$ \\
SHORT-RUN TOTAL & CLAIM & $-0.025^{* * *}$ & $0.221^{* *}$ & $-0.938^{* * * *}$ \\
LONG-RUN DIRECT & CLAIM & 0.001 & 0.001 & $-0.114^{* * *}$ \\
LONG-RUN INDIRECT & CLAIM & $-0.022^{* * *}$ & $0.274^{* *}$ & $-0.876^{* * * *}$ \\
LONG-RUN TOTAL & CLAIM & $-0.021^{* *}$ & $0.234^{* *}$ & $-0.994^{* * *}$
\end{tabular}

Table 6.

The spatial effect

Notes: Table reports the contemporaneous impacts for significant variables. ***, ** and * significant at the $0.01,0.05$ and 0.10 level, respectively 
These reductions will persist over time. On the other hand, a 1\% increase in the total asset, will produce an increase in risk due to the risk-taking channel. By disaggregating direct and indirect effect, we can note that the majority of the total effect comes from the indirect or "spillover" effects. Moreover, direct short-term effects seem to be substantially lower than direct long-run ones. This could mean that it takes time for the risk changes to stabilise completely.

We observe that there is an indirect and total negative effect on TIER 1 and a positive one on total assets. This suggests that, on average, among banks, risk decreases (increases) when one of these variables increases (decrease) in neighbouring banks. For example, if TIER 1 of neighbouring banks increases by one percentage point, credit risk will decrease by 2.21 basis points. Concentrating on stock return, we can see how an increase in the bank-specific stock return will have a positive impact in reducing its CDS spread but also on neighbouring banks, and thus of the banking system as a whole (elasticity $=-0.822$ ). When there is a $1 \%$ increase in the stock return of bank $i$, the CDS spreads of the other 21 banks fall by a total of 82.2 basis points. This result implies that the dynamics of the equity markets of "neighbouring" banks are important. In other words, banks with strong financial links can influence the credit risk of other banks through their market conditions. The total effect is confirmed statistically significant: the indirect effect of stock return seems to be relevant both in the long and short run. These spillover effects suggest the key role of the financial market, asset price and investor behavioural on default risk, highlighting the importance of financial market integration in the Eurozone. As Table 6 reports, the spatial spillover impact is greater than the direct effect. This shows how the European stock market has a great impact on the individual bank, so how the herd effect potentially induces the contagion.

Figure 2 exhibits the indirect impacts concerning TIER 1 (up) and total asset (down). The effects are evaluated using a uniform variation of one percentage point. We report the indirect short and long-run effects for each bank, using the CLAIM matrix. The highest indirect beneficial effect (TIER 1) is for KBC followed by DBK. Turning to total asset, we observe a greater homogeneity of the effects. In this case, BNP and DBK are the banks that have the greatest impact, i.e. where the CDS spread is more reactive to a change in the total assets of the neighbours. In this case, we are faced with what Debarsy et al. (2018) call the "bad neighbourhood" effect.

These findings highlight the importance of considering spillovers while analysing the contagion effect. Variations of the total asset and of TIER 1, for each bank of the Eurozone, may cause unexpected consequences in term of effects systemic risk.

\subsection{Robustness analysis}

In the previous section, we estimated the model using the CLAIM matrix. In this section, we carry out robustness checks to confirm the validity of our results. Especially, we use two different spatial weighted matrices. Table 7 reports the findings assuming these alternative matrices: the financial linkages matrix (FLink as in Dell'Erba et al., 2013; Kişla and Önder, 2018) and the stock correlation matrix (STOCK as in Ferndandez, 2011; Eder and Keiler, 2015; Blasques et al., 2016; Catania and Billé, 2017). To avoid the endogeneity problem, we use data before 2008. As Table 7 suggests, we find the same qualitative results. Despite differences in fit, however, the parameter estimates are robust against W-CLAIM's specifications and none of the qualitative implications of previous results changes.

Moreover, we compare the results obtained with spatial econometric methods with ordinary econometric methods. In Table 8 , we present the results of the linear model. In particular, we use the pooled ordinary least square (OLS) and least square dummy variable (LSDV). The findings show that the coefficients of stock returns, volatility, 


\section{8}



Figure 2.

The Impacts

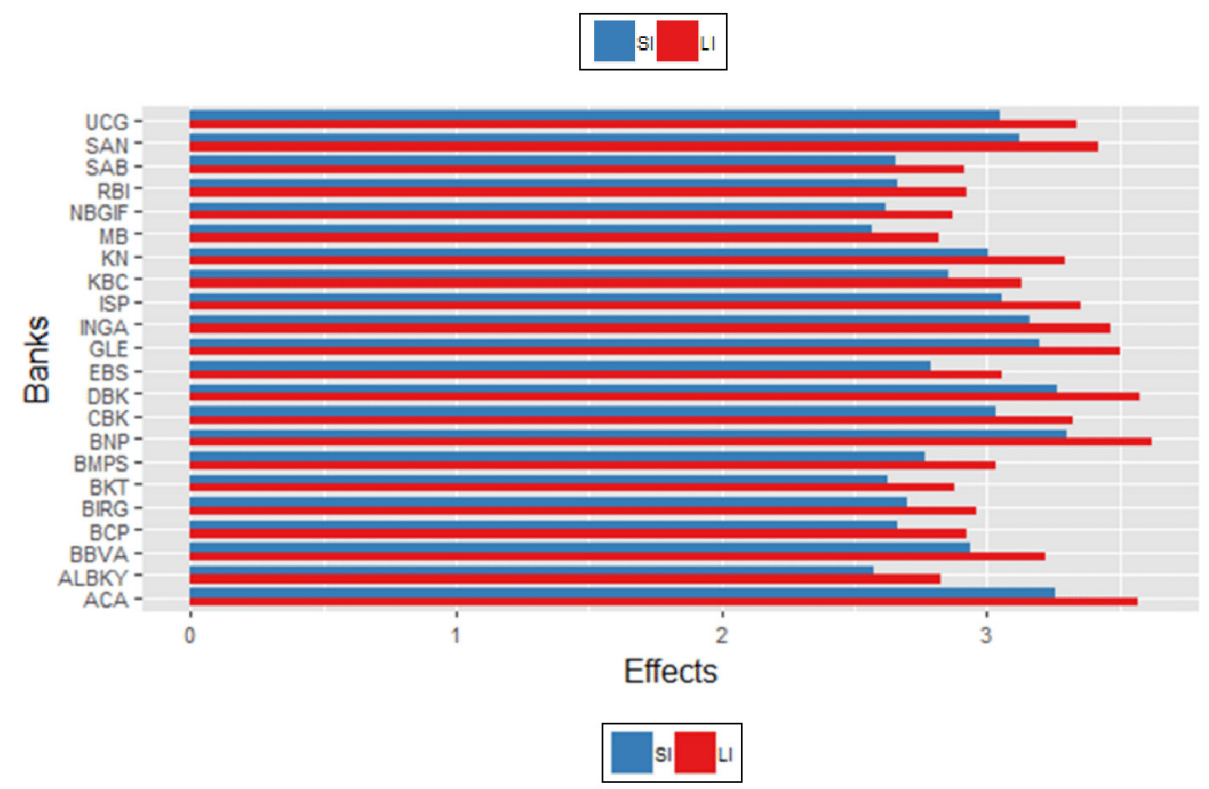

Notes: Top-panel shows the contemporaneous impact of a change in Tier 1 (1 ppt increase); down-panel shows the contemporaneous impact of a change in total asset (1 ppt increase); $\mathrm{SI}=$ shortindirect (blue bars); LI = long-indirect (red bars)

term-spread and dummy are significantly negative, which is in line with previous results. In general, the estimated explanatory variables remain consistent with previous findings, which confirms the robustness of the main results. However, these models have not been able to capture and reveal the impact of spillover effects, i.e. contagion. 


\begin{tabular}{|c|c|c|}
\hline Variables & Stock & FLink \\
\hline$\varphi$ & $-0.070 * * *(0.021)$ & $-0.054^{* * *}(0.021)$ \\
\hline$\eta$ & $0.083 * * * *(0.026)$ & $0.062 * *(0.025)$ \\
\hline$\rho$ & $0.740 * * *(0.018)$ & $0.655^{* * *}(0.020)$ \\
\hline \multicolumn{3}{|l|}{$\beta_{1}$} \\
\hline TIER 1 & $0.001(0.001)$ & $0.001(0.001)$ \\
\hline T.A. & $-0.002(0.005)$ & $-0.001(0.005)$ \\
\hline LEV & $-0.184(0.189)$ & $-0.054(0.185)$ \\
\hline Stock return & $-0.074 * * *(0.021)$ & $-0.085 * * *(0.022)$ \\
\hline Equity $\sigma$ & $-0.835 * * *(0.019)$ & $-0.792 * * *(0.019)$ \\
\hline Term-spread & $-0.001 * * *(0.000)$ & $-0.001^{* * *}(0.000)$ \\
\hline Shadow-rate & $0.002(0.018)$ & $0.081(0.074)$ \\
\hline Dummy & $0.003 * * *(0.000)$ & $0.071 *(0.030)$ \\
\hline \multicolumn{3}{|l|}{$\beta_{2}$} \\
\hline TIER 1 & $-0.005^{* *}(0.002)$ & $-0.009 * *(0.004$ \\
\hline T.A. & $0.122 *(0.067)$ & $0.114 * * *(0.051)$ \\
\hline LEV & $-0.397(0.391)$ & $-0.069(0.488)$ \\
\hline Stock return & $-0.188 * * * *(0.041)$ & $-0.232 * * *(0.041)$ \\
\hline Equity $\sigma$ & $0.014(0.052)$ & $-0.039(0.061)$ \\
\hline Term-spread & $0.001(0.002)$ & $0.012(0.008)$ \\
\hline Shadow-rate & $-0.002(0.018)$ & $-0.081(0.075)$ \\
\hline Dummy & $-0.003 * * *(0.000)$ & $-0.071 * *(0.030)$ \\
\hline Obs. & 2,332 & 2,332 \\
\hline$R$-squared & 0.34 & 0.34 \\
\hline $\log \mathrm{L}$ & $1,759.69$ & $1,668.03$ \\
\hline AIC & $-3,479.39$ & $-3,296.06$ \\
\hline No. of banks & 22 & 22 \\
\hline
\end{tabular}

Notes: Estimation from the dynamic spatial Durbin model. In column 2, the results with a STOCK weighted matrix. Column 3 shows the results with Financial Link weighted matrix. Standard errors in parentheses. ***,** and * significant at the $0.01,0.05$ and 0.10 level, respectively

Table 7.

The estimate of different weighted matrix

\begin{tabular}{lcr}
\hline Variables & Pooled OLS & \multicolumn{1}{c}{ LSDV } \\
\hline Cons & $-0.051(0.137)$ & $-0.189(0.233)$ \\
TIER 1 & $-0.001(0.001)$ & $-0.001(0.002)$ \\
T.A. & $-0.003(0.003)$ & $-0.002(0.006)$ \\
LEV & $0.132(0.156)$ & $0.268(0.221)$ \\
Stock return & $-0.487^{* * * *}(0.023)$ & $-0.493^{* * * *}(0.023)$ \\
Equity $\sigma$ & $-0.119^{* * * *}(0.021)$ & $-0.153^{* * * *}(0.024)$ \\
Term-spread & $-0.012^{* *}(0.005)$ & $-0.001^{* *}(0.000)$ \\
Shadow-rate & $-0.022(0.036)$ & $-0.010(0.038)$ \\
Dummy & $-0.036^{* * * *}(0.011)$ & $-0.036^{* * * *}(0.011)$ \\
Obs. & 2,332 & 2,332 \\
R-squared & 0.18 & 0.18 \\
LogL & $1,038.28$ & $1,044.84$ \\
AIC & $-2,060.57$ & $-2,029.69$
\end{tabular}

Notes: Estimation from the pooled OLS and least square dummy variable (LSDV) model. Standard errors in parentheses. ***, ** and * significant at the $0.01,0.05$ and 0.10 level, respectively

Table 8.

Model robustness test 


\section{Discussion and policy implications}

The research offers findings that contribute to the literature on contagion (systemic risk): from the identification of credit risk determinants to the measurement of risk spillover effects (stress-test). These concepts (contagion and spillover) have become central to the economic policy debate following the global financial crisis. In fact, the financial crisis has stimulated the development of international literature aimed at measuring and regulating contagion. In the contest of the banking environment, our approach meets several current policies needs of banking regulators. Stress testing has become a standard tool in the hands of regulators; however, current implementations only consider individual losses without considering the cross-section dimension. In particular, through spatial-temporal analysis, we can provide a framework that takes into account direct-indirect "spatial" effects in the short and long term. Although other approaches can be used for this purpose, the framework we implement is able to capture spillover effects transparently and straightforwardly. Therefore, our results support the discussion on the straightforwardness of regulation and the estimation of contagion. Our approach is in line with Haldane (2011), which suggest three main principles of "good regulation", namely, simplicity, robustness and timeliness.

The default of Lehman Brothers and the sovereign debt crisis showed how much the choices of a single subject (financial firm) are able to influence those of others (financial system). Indeed, contagion risk, due to its multiple nature, remains a research strand still to be explored. For example, one aspect that should undoubtedly be taken into account is the close interconnection between systemic risk, financial regulation and monetary policy: the so-called risk-taking channel.

Financial regulation aims to limit the individual risk of institutions in a system. Each financial firm has an incentive to take risks unless they internalise the negative externalities (arising from their failure). Hence, the existing financial regulations should include some mechanisms that discourage institutions from taking risks and share the costs of negative externalities among system participants.

The financial crisis has led to a series of reforms of financial regulation and supervision aimed at reducing the likelihood of future financial crises. Specifically, the Basel Committee on Banking Supervision undertook a major reform of the banking regulatory framework. Basel III introduced a non-risk-based leverage ratio (LR). The objective is to "limit the accumulation of excessive leverage in the banking sector to avoid destabilising processes of leverage reduction that may damage the financial system in general and the economy" (BCBS, 2014). The rationale is, therefore, to make the financial system more stable and robust, avoiding that in the future new systemic crises may arise again. Nevertheless, this non-risk based measure has raised concerns about the possible increase in risk-taking by banks. In fact, banks could offset the benefits of requiring banks bound by the LR to hold more capital. These banks may be tempted to increase their risk-taking by offsetting the benefits of having to hold more capital. Therefore, this rule, while its objective is to make the financial system more stable, under current conditions, it could stimulate more significant risk-taking. Several studies (Samitas and Polyzos, 2015; CE, 2019) show how the tighter regulation of Basell III, could result in a deterioration of the "economy's performance concerning the recovery from a crisis and its contagion effects" (Samitas and Polyzos, 2015). Furthermore, the monetary policy can also have an impact on banks' perception of risk causing excessive risk-taking (Neuenkirch and Nöckel, 2018; Bubeck et al., 2019). For example, an expansive monetary policy may lead banks to seek riskier investments to achieve nominal return targets. Albertazzi et al. (2020), show how that the most stressed Eurozone banks most likely used the additional liquidity (from the three-year refinancing operations) to purchase domestic sovereign debt. This has strengthened the risk link 
between sovereign and banks. Bubeck et al. (2019), show that negative policy rates have led to "reach for yield" banking behaviour.

What implications do our findings have for policymakers? Firstly, our findings suggest that an increase in the total asset (risk-taking) of all system also affects individual credit risk. The belief of bailout due to the "too big to fail" effect eases excessive risk-taking dynamics among banks. Therefore, in addition to establishing prudential requirements based on individual assessments of each bank in isolation, supervisors should examine the interaction of each bank's risk with the specific characteristics of the others. Secondly, regulators should take the opportunity to improve the quality, consistency and transparency of the capital base. Our analysis shows that a key factor in reducing contagion is the capital adequacy (Tier 1). According to Oliveira and Raposo (2019), supervisors should pay more attention to constraints in the use of internal models to reduce the unjustified variability in banks' calculations of risk weights. The greater freedom given to banks using sophisticated approaches in calculating their capital requirements may result in heterogeneity in the capital base, i.e. on capital adequacy requirements. Thirdly, the work sheds light on the role played by the ECB in managing the banking contagion (domino effect). We show that financial stability ECB policy is not - unfortunately - still today a priority or at least secondary, compared to the inflation target of $2 \%$ annual growth rate. The objective of financial stability should be incorporated into a framework of main policies to avoid selffulfilling crisis, i.e. to overcome the domino effect of contagion (which is not necessarily the cause of the structural conditions of the banks).

In general, there is a trade-off between additional loss-absorbing capacity, monetary policy and taking potentially higher banking risks. Obviously, greater security improves the entire wealth creation system, strengthens solidity and ensures less fluctuation in economic growth. However, it could stimulate financial institutions to take more risk (or decline in loans), and thus undermine regulatory efforts, especially in the European context where these additional challenges stem from the complexity of the architecture of the financial supervision system. In total, 12 years after the failure of Lehman Brothers, the use of macroprudential policies, i.e. measures regarding contagion and systemic risk, are not yet clear and defined.

\section{Conclusion}

In this study, we focus on the financial contagion amongst Eurozone banks, adopting a dySDM. In this way, we are able to consider the two components of contagion risk: the time dimension and the cross-section one. The results show that CDS spread changes of one bank, depend both on its own lagged and, because of spatial interconnection, on the other banks' ones. Our findings suggest that neglecting the "neighbouring effect", equity volatility, stock returns and term-spread are three important factors affecting CDSs, consistently to literature. On the other hand, the neighbours' variables such as the total assets, Tier 1 and stock return, are also significant determiners of a bank's CDS spread. These results are also testified by the stress-test analysis, where we have studied the marginal effect on credit risk (direct/spillover) due to a change in fundamental variables in the short and long run. According to Horace (Epistulae: I, 18, v 84): "you too are in danger when your neighbour's house is on fire".

We guess that our paper gives a contribution to the research on systemic risk, through an analysis that involves both the spatial and temporal point of view, with reference to the Eurozone banking sector. It might be interesting to extend this study to other financial sectors, to consider the evolution of the Spatio-temporal interconnection under a worldwide perspective. 
1. In recent years, the study of spillover effects has also focussed on sectors other than banking. For example, there are several recent works analysing risk spillover effects in the energy market (Ji et al., 2018; Batten et al., 2019; Singh et al., 2019), commodities (Handika and Putra, 2017; Ji et al., 2020), cryptocurrency markets (Xu et al., 2020; Kostika and Laoposis, 2019). For example, Batten et al. (2019) investigate the temporal nature of integration between energy (oil, coal and gas) and an Asian stock market portfolio set up 10 key stock markets including China and Japan. Singh et al. (2019) explore the system-wide shock spillover connectedness of crude oil and select global asset indicators from commodities, stocks, bonds and currency.

2. We choose these banks according to data availability of datastream database.

3. The list is available here: www.fsb.org/wp-content/uploads/P211117-1.pdf

4. The equity volatility is converted to end-of-month data to have the same frequency of estimation.

5. Due to space limitations, we do not report the methodological aspects of Shadow-rate estimation. However, they are available on request.

6. We know that this matrix could be endogenous. However, the correlation between the average CDS spread and the average logarithmic return ( $t-12)$ is not present $(0.0001)$. Therefore, as point out by Eder and Keiler (2015), the matrix can be treated as exogenous. Moreover, several papers use this stock correlation matrix (Eder and Keiler, 2015; Blasque et al., 2016; Catania and Billè, 2017; Foglia and Angelini, 2019).

7. Source: Coordinated Portfolio Investment Survey (CPIS).

8. It is important to keep in mind that the interaction between banks (i.e. propagation channels) could evolve over time to some extent, because the banking system may undergo structural changes and crises' dynamics are often different over time. Therefore, further development could be to consider the structure of the banking network that changes each period. Hence, extend the basic model by adding a time-varying diagonal covariance matrix to take into account the updated status dependency at each observation. However, as Blasques et al. (2016) show, the results with a time-varying diagonal covariance matrix, are very similar to the standard model, highlighting the robustness of the model with a static diagonal covariance matrix.

9. We find that the model is stable, i.e. the stable of spatio-temporal processes condition $\varphi+\eta+$ $\rho<1$ is satisfied.

\section{References}

Adrian, T. and Brunnermeier, M.K. (2016), “CoVaR”, American Economic Review, Vol. 106 No. 7, p. 1705.

Albertazzi, U., Barbiero, F., Marqués-Ibáñez, D., Popov, A.A., d’Acri, C.R. and Vlassopoulos, T. (2020), "Monetary policy and bank stability: the analytical toolbox reviewed", working papers No. 2377, European Central Bank.

Alexander, C. and Kaeck, A. (2008), "Regime dependent determinants of credit default swap spreads", Journal of Banking and Finance, Vol. 32 No. 6, pp. 1008-1021.

Angelini, E. and Ortolano, A. (2016), "CDS spreads and balance-sheet ratios in the banking sector: an empirical analysis on the Mediterranean Europe", International Journal Application Business Economics Research, Vol. 14, pp. 4331-4343.

Annaert, J., De Ceuster, M., Van Roy, P. and Vespro, C. (2013), "What determines Euro area bank CDS spreads?", Journal of International Money and Finance, Vol. 32, pp. 444-461. 
Apergis, N., Christou, C. and Kynigakis, I. (2019), "Contagion across US and European financial markets: evidence from the CDS markets", Journal of International Money and Finance, Vol. 96, pp. 1-12.

Barth, J.R. and Wihlborg, C. (2016), “Too big to fail and too big to save: dilemmas for banking reform”, National Institute Economic Review, Vol. 235 No. 1, pp. $27-39$.

Batten, J.A., Kinateder, H., Szilagyi, P.G. and Wagner, N.F. (2019), “Time-varying energy and stock market integration in Asia", Energy Economics, Vol. 80, pp. 777-792.

BCBS (2014), "Basel III leverage ratio framework and disclosure requirements", Technical Report, Bank for International Settlements (BIS), BCBS (Basel Committee on Banking Supervisors), Basel.

Beccalli, E., Anolli, M. and Borello, G. (2015), “Are European banks too big? Evidence on economies of scale", Journal of Banking and Finance, Vol. 58, pp. 232-246.

Benbouzid, N., Leonida, L. and Mallick, S.K. (2018), "The non-monotonic impact of bank size on their default swap spreads: cross-country evidence", International Review of Financial Analysis, Vol. 55, pp. 226-240.

Bhar, R. (2016), "Interconnectedness in credit market: an empirical investigation using UK and US CDS data", Journal of Data Science, Vol. 14 No. 3, pp. 479-490.

Billio, M., Getmansky, M., Lo, A.W. and Pelizzon, L. (2012), "Econometric measures of connectedness and systemic risk in the finance and insurance sectors", Journal of Financial Economics, Vol. 104 No. 3, pp. 535-559.

Blasques, F., Koopman, S.J., Lucas, A. and Schaumburg, J. (2016), "Spillover dynamics for systemic risk measurement using spatial financial time series models", Journal of Econometrics, Vol. 195 No. 2, pp. 211-223.

Bonaccorsi di Patti, E., Felici, R. and Signoretti, F.M. (2016), "Euro area significant banks: main differences and recent performance", working paper 306, Bank of Italy.

Bubeck, J., Maddaloni, A. and Peydró, J.L. (2019), "Negative monetary policy rates and systemic banks' risk-taking: evidence from the Euro area securities register", Working paper, Mimeo.

Calabrese, R., Elkink, J.A. and Giudici, P.S. (2017), "Measuring bank contagion in Europe using binary spatial regression models", Journal of the Operational Research Society, Vol. 68 No. 12, pp. 1503-1511.

Catania, L. and Billé, A.G. (2017), "Dynamic spatial autoregressive models with autoregressive and heteroskedastic disturbances", Journal of Applied Econometrics, Vol. 32 No. 6, pp. 1178-1196.

CE (2019), "EU implementation of the final basel III framework - impact on the banking market and on the real economy", working paper, Copenhagen Economics.

Cerrato, M., Crosby, J., Kim, M. and Zhao, Y. (2017), "The joint credit risk of UK global-systemically important banks", Journal of Futures Markets, Vol. 37 No. 10, pp. 964-988.

Chiaramonte, L. and Casu, B. (2013), "The determinants of bank CDS spreads: evidence from the financial crisis", The European Journal of Finance, Vol. 19 No. 9, pp. 861-887.

Chodnicka-Jaworska, P. and Jaworski, P. (2017), "Fundamental determinants of credit default risk for European and American banks", Journal of International Studies, Vol. 10 No. 3, pp. 51-63.

Collin-Dufresn, P., Goldstein, R.S. and Martin, J.S. (2001), "The determinants of credit spread changes", The Journal of Finance, Vol. 56 No. 6, pp. 2177-2207.

Daly, K., Batten, J.A., Mishra, A.V. and Choudhury, T. (2019), "Contagion risk in global banking sector", Journal of International Financial Markets, Institutions and Money, Vol. 63, p. 101136.

De Jonghe, O. (2010), "Back to the basics in banking? A micro-analysis of banking system stability", Journal of Financial Intermediation, Vol. 19 No. 3, pp. 387-417. 
Debarsy, N., Dossougoin, C., Ertur, C. and Gnabo, J.Y. (2018), "Measuring sovereign risk spillovers and assessing the role of transmission channels: a spatial econometrics approach", Journal of Economic Dynamics and Control, Vol. 87, pp. 21-45.

Debarsy, N., Ertur, C. and LeSage, J.P. (2012), "Interpreting dynamic space-time panel data models", Statistical Methodology, Vol. 9 Nos 1/2, pp. 158-171.

Dell'Erba, S., Baldacci, E. and Poghosyan, T. (2013), "Spatial spillovers in emerging market spreads", Empirical Economics, Vol. 45 No. 2, pp. 735-756.

Diebold, F.X. and Yilmaz, K. (2014), "On the network topology of variance decompositions: measuring the connectedness of financial firms", Journal of Econometrics, Vol. 182 No. 1, pp. 119-134.

Düllmann, K. and Sosinska, A. (2007), "Credit default swap prices as risk indicators of listed German banks", Financial Markets and Portfolio Management, Vol. 21 No. 3, pp. 269-292.

Eder, A. and Keiler, S. (2015), "Cds spreads and contagion amongst systemically important financial institutions - a spatial econometric approach", International Journal of Finance and Economics, Vol. 20 No. 4, pp. 291-309.

Elhorst, J.P. (2014), Spatial Econometrics: From Cross-Sectional Data to Spatial Panels, Springer, Berlin.

Elhorst, P., Zandberg, E. and De Haan, J. (2013), “The impact of interaction effects among neighbouring countries on financial liberalization and reform: a dynamic spatial panel data approach", Spatial Economic Analysis, Vol. 8 No. 3, pp. 293-313.

Fan, H., Gou, Q., Peng, Y. and Xie, W. (2020), "Spillover effects of capital controls on capital flows and financial risk contagion”, Journal of International Money and Finance, Vol. 105, p. 102189.

FBF (2015), "French banks and European banking reforms", Technical report, Federation Bancaire Francaise.

Fernandez, V. (2011), "Spatial linkages in international financial markets”, Quantitative Finance, Vol. 11 No. 2, pp. 237-245.

Foglia, M. and Angelini, E. (2020), "From me to you: measuring connectedness between eurozone financial institutions", Research in International Business and Finance, Vol. 54, p. 101238.

Foglia, M. and Angelini, E. (2019), "The Time-Spatial dimension of eurozone banking systemic risk", Risks, Vol. 7 No. 3, p. 75.

Forbes, K.J. and Rigobon, R. (2002), "No contagion, only interdependence: measuring stock market comovements", The Journal of Finance, Vol. 57 No. 5, pp. 2223-2261.

Fuerst, F., McAllister, P. and Sivitanides, P. (2015), "Flight to quality? An investigation of changing price spreads in commercial real estate markets", Studies in Economics and Finance, Vol. 32 No. 1, pp. 2-16.

Ghulam, Y. and Doering, J. (2018), "Spillover effects among financial institutions within Germany and the United Kingdom", Research in International Business and Finance, Vol. 44, pp. 49-63.

Giudici, P. and Parisi, L. (2018), "Corisk: credit risk contagion with correlation network models”, Risks, Vol. 6 No. 3, p. 95.

Gubareva, M. and Borges, M.R. (2016), "Typology for flight-to-quality episodes and downside risk measurement", Applied Economics, Vol. 48 No. 10, pp. 835-853.

Haldane, A. (2011), "To navigate economic storms we need better forecasting”, New Scientist, Vol. 13, pp. 2842.

Handika, R. and Putra, S. (2017), "Commodities returns' volatility in financialization era”, Studies in Economics and Finance, Vol. 34 No. 3, pp. 344-362.

Ji, Q., Bahloul, W., Geng, J.B. and Gupta, R. (2020), "Trading behaviour connectedness across commodity markets: evidence from the hedgers' sentiment perspective", Research in International Business and Finance, Vol. 52, pp. 101-114. 
Ji, Q., Liu, B.Y., Nehler, H. and Uddin, G.S. (2018), "Uncertainties and extreme risk spillover in the energy markets: a time-varying copula-based CoVaR approach", Energy Economics, Vol. 76, pp. 115-126.

Jing, Z., Elhorst, J.P., Jacobs, J.P. and de Haan, J. (2018), “The propagation of financial turbulence: interdependence, spillovers, and direct and indirect effects", Empirical Economics, Vol. 55 No. 1, pp. 169-192.

Jubinski, D. and Lipton, A.F. (2012), "Equity volatility, bond yields, and yield spreads", Journal of Futures Markets, Vol. 32 No. 5, pp. 480-503.

Bad or good neighbours

Kalemli-Ozcan, S., Sorensen, B. and Yesiltas, S. (2012), "Leverage across firms, banks, and countries", Journal of International Economics, Vol. 88 No. 2, pp. 284-298.

Khiewngamdee, C., Yamaka, W. and Sriboonchitta, S. (2017), "Forecasting Asian credit default swap spreads: a comparison of multi-regime models", in Kreinovich, V., Sriboonchitta, S. and Huynh, V-N. (Eds), Robustness in Econometrics, Springer, Cham, pp. 471-489.

Kiff, J., Elliott, M.J.A., Kazarian, E.G., Scarlata, J.G. and Spackman, C. (2009), “Credit derivatives: systemic risks and policy options?”, Working paper 9-254, International Monetary Fund.

Kim, D.H., Loretan, M. and Remolona, E.M. (2010), "Contagion and risk premia in the amplification of crisis: evidence from Asian names in the global CDS market", Journal of Asian Economics, Vol. 21 No. 3, pp. 314-326.

Kışla, G.H. and Önder, A.Ö. (2018), "Spatial analysis of sovereign risks: the case of emerging markets", Finance Research Letters, Vol. 26, pp. 47-55.

Krippner, L. (2015). "Zero lower bound term structure modeling: a practitioner's guide”, Springer.

Lee, H.H. and Hyun, J.S. (2019), "The asymmetric effect of equity volatility on credit default swap spreads", Journal of Banking and Finance, Vol. 98, pp. 125-136.

LeSage, J. and Pace, R. (2014), "The biggest myth in spatial econometrics”, Econometrics, Vol. 2 No. 4, pp. 217-249.

Li, M.C. and Fu, X.M. (2017), "Determinants of credit default swap spreads: a four-market panel data analysis", Journal of Finance and Economics, Vol. 5 No. 1, pp. 9-31.

Merton, R.C. (1974), "On the pricing of corporate debt: the risk structure of interest rates", The Journal of Finance, Vol. 29 No. 2, pp. 449-470.

Milcheva, S. and Zhu, B. (2016), "Bank integration and co-movements across housing markets", Journal of Banking and Finance, Vol. 72, pp. S148-S171.

Mili, M. (2018), "Systemic risk spillovers in sovereign credit default swaps in Europe: a spatial approach", Journal of Asset Management, Vol. 19 No. 2, pp. 133-143.

Neuenkirch, M. and Nöckel, M. (2018), "The risk-taking channel of monetary policy transmission in the euro area", Journal of Banking and Finance, Vol. 93, pp. 71-91.

Oliveira, V.B. and Raposo, C. (2019), "How did regulation and market discipline influence banking distress in Europe?”, Studies in Economics and Finance, Vol. 37 No. 1.

Pattipeilohy, C., Bräuning, C., van den End, J.W. and Maas, R. (2017), "Assessing the effective stance of monetary policy: a factor-based approach” Working paper 575, Netherlands Central Bank, Research Department, Amsterdam.

Pino, G. and Sharma, S.C. (2019), "On the contagion effect in the US banking sector”, Journal of Money, Credit and Banking, Vol. 51 No. 1, pp. 261-280.

Sahling, C. (2017), "Interdependence of the European Central bank's policy and financial stability in the eurozone", Journal of the Ural State University of Economics, Vol. 71 No. 3, pp. 66-76.

Samaniego-Medina, R., Trujillo-Ponce, A., Parrado-Martínez, P. and di Pietro, F. (2016), "Determinants of bank CDS spreads in Europe”, Journal of Economics and Business, Vol. 86, pp. 1-15. 
Samitas, A. and Polyzos, S. (2015), “To basel or not to basel? Banking crises and contagion”, Journal of Financial Regulation and Compliance, Vol. 23 No. 3, doi: 10.1108/JFRC-11-2014-0045.

Singh, V.K., Kumar, P. and Nishant, S. (2019), "Feedback spillover dynamics of crude oil and global assets indicators: a system-wide network perspective”, Energy Economics, Vol. 80, pp. 321-335.

Tamakoshi, G. and Hamori, S. (2014), "Spillovers among CDS indexes in the US financial sector", The North American Journal of Economics and Finance, Vol. 27, pp. 104-113.

Tang, D.Y. and Yan, H. (2017), "Understanding transactions prices in the credit default swaps market", Journal of Financial Markets, Vol. 32, pp. 1-27.

Thornton, J. and di Tommaso, C. (2018), "Credit default swaps and regulatory capital relief: evidence from European banks", Finance Research Letters, Vol. 26, pp. 255-260.

Tonzer, L. (2015), "Cross-border interbank networks, banking risk and contagion”, Journal of Financial Stability, Vol. 18, pp. 19-32.

Witowschi, I.R.B. and Luca, F.A. (2016), "Bank Capital, risk and performance in European banking. A case study on seven banking sectors", Prague Economic Papers, Vol. 25 No. 2, pp. 127-142.

Wynne, M.A. and Koech, J. (2012), “One-size-fits-all monetary policy”, Europe and the U.S.”, Economic Letter, Vol. 7.

Xu, Q., Zhang, Y. and Zhang, Z. (2020), "Tail-risk spillovers in cryptocurrency markets”, Finance Research Letters, p. 101453.

Zhang, W.G., Mo, G.L., Liu, F. and Liu, Y.J. (2018), "Value-at-risk forecasts by dynamic spatial panel GJR-GARCH model for international stock indices portfolio", Soft Computing, Vol. 22 No. 16, pp. 5279-5297.

Zhang, B.Y., Zhou, H. and Zhu, H. (2009), "Explaining credit default swap spreads with the equity volatility and jump risks of individual firms", Review of Financial Studies, Vol. 22 No. 12, pp. 5099-5131.

\section{Further reading}

Alemany, A., Ballester, L. and González-Urteaga, A. (2015), "Volatility spillovers in the European bank CDS market”, Finance Research Letters, Vol. 13, pp. 137-147.

Brownlees, C. and Engle, R.F. (2017), "SRISK: a conditional capital shortfall measure of systemic risk", Review of Financial Studies, Vol. 30 No. 1, pp. 48-79.

Hellwig, M. (2014), "Systemic risks and macro-prudential policy", in Houben, A., Nijskens, R. and Teunissen, M. (Eds), Putting Macroprudential Policy to Work, De Nederlandse Bank, Amsterdam, pp. 42-77.

Kostika, E. and Laopodis, N.T. (2019), "Dynamic linkages among cryptocurrencies, exchange rates and global equity markets", Studies in Economics and Finance. doi: 10.1108/SEF-01-2019-0032.

Corresponding author

Matteo Foglia can be contacted at: matteo.foglia@unich.it

For instructions on how to order reprints of this article, please visit our website:

www.emeraldgrouppublishing.com/licensing/reprints.htm

Or contact us for further details: permissions@emeraldinsight.com 